\title{
Systematizing The Promotion of Reading: PLIA, An Interactive Platform
}

\author{
María Parra Soler ${ }^{1,}$, , Andrés Cabrera-Lozoya ${ }^{2}$ and Amando López Valero ${ }^{3}$ \\ ${ }^{1}$ Associate Professor at Department of Didactics of Language and Literature, University of Murcia, Spain \\ ${ }^{2}$ PhD., Associate Professor at Department of Applied Physics, Technical University of Cartagena, Spain \\ ${ }^{3}$ PhD., Fulltime Professor at Department of Didactics of Language and Literature, University of Murcia, Spain
}

\begin{abstract}
This article introduces PLIA platform, an innovative tool based on the portfolio of the Common European Framework of Reference for Languages, for students to develop and self-assess their comprehension, speed and reading action. Its main objectives are to systematize reading work, establish a shared assessment strategy, create an instrument for collecting information and finally offer the students an analysis of the evolution in their metacognitive development as readers. PLIA has been evaluated with a sample of 220 users of primary and secondary education during a school year, obtaining a trend of improvement of nearly $15 \%$ on average in terms of comprehension, speed and reading action. The number of readings per school term increased by more than $70 \%$ on average due to the users' high degree of motivation since they knew their results and improvement areas throughout their reading process. This new system involves the whole family in their children's learning. It offers a point of reflection to establish objectives and learning strategies, self-evaluation and peer evaluation. It also helps the faculty to design the linguistic project of the centers, allowing institutions to verify good academic results and making it possible to obtain a quantitative result of the reading level of a specific group, a full grade, or the entire center.
\end{abstract}

Keywords: PLIA platform, reading promotion, self-assessment tool.

\section{Introduction}

On July 23, 2020, the Organization for Economic Cooperation and Development (OECD) published the reading data of the Pisa report. In this study, Spain fell 19 points compared to the last report, obtaining the $496^{\text {th }}$ position in 2015 and the $477^{\text {th }}$ in 2018 , the worst result in 14 years.

To improve and achieve truly optimal results, Spain needs a method that guarantees the acquisition of good reading skills for young people, as well as adequate training for those who are committed to promote reading (Vázquez, 2010) by giving them the right tools.

So far, the strategies used to promote reading have been applied without any systematization. To make up for this deficiency, this work presents a method that could significantly help to improve the previous scores. The method adopts the use of the portfolio tool to the Common European Framework of Reference for languages (Council of Europe, 2002) to improve reading competence which we have called My Reader Portfolio, hence MRP. 


\section{2nd World Conference on Teaching and Education}

This same constructivist approach to reading comprehension has been carried out by Andrés Calero (Guisado, 2008) in order to give primary school students control over their own construction of reading process. However, our contribution will consist of both comprehension, speed and reading action and will be based, on the one hand, on establishing the necessary parameters to check if the student's reading competence is at the same level as his curricular competence in all stages of teaching and, on the other hand, it is a transversal approach, since it proposes the portfolio as an evaluation tool of the linguistic competence of the curriculum of primary (Decree No. 198, 2014), secondary (Decree No. 220, 2015) and baccalaureate (Decree No. 221, 2015) education. For this, the project addresses both the horizontal dimension of the Common European Framework, which refers to the specification of the content to be evaluated, that is, of the learning standards, as well as its vertical dimension - the level scales -, that helps us to establish the criteria with which to evaluate the achievement of those standards.

Additionally, the portfolio is proposed as a class work instrument, as its use may imply a change in the work methodology in the classroom, in accordance with a formative evaluation. Other assessment instruments are also presented and integrated into the teaching-learning process, which favour the student's reflection and enhance their self-assessment and autonomy (Moreno-Fernández \& Moreno-Crespo, 2017).

The following section highlights the role of the EPL (European Portfolio of Languages) in the field of reading literacy and its relationship with the proposed method. Then, the contribution of the proposed method to the basic competences is described and, finally, the structure of the method and the methodology of implementation are developed as it has been developed in the PLIA platform (interactive platform for the promotion of reading).

\subsection{The Common European Framework of Reference and the European Portfolio of Languages (EPL) and their contribution to reading literacy}

On the one hand, the Framework helps us to develop the following points:

1. Specify the content of the tests and exams which is evaluated from its horizontal dimension.

2. Establish the criteria with which the achievement of a learning objective is determined and how the performance is interpreted from its vertical dimension.

3. Describe the levels of linguistic proficiency in tests and exams, thus allowing comparisons to be made based on their horizontal and vertical dimensions.

Teachers will be especially interested in working with the first two uses of the Framework and institutions with the third.

On the other hand, MRP has two essential functions. In the first place, the pedagogical and formative, in the sense of recording the learning process, and secondly, the informative, which collects the results or products of this process, either through the collection of language certificates or of linguistic performances. The portfolio encourages the acquisition of a competent reading for students because it allows them to establish their needs and objectives. It develops the students' ability to reflect on their learning process and to self-assess their progress in order to determine their achievements and shortcomings. Thus, they can consequently take the necessary decisions to advance in their learning what, in turn, enhances their autonomy and motivation. 


\section{2nd World Conference on Teaching and Education}

\section{9-21 February, $2021 \quad$ Vienna, AUSTRIA}

MRP is a pioneer reading method that offers both a tool for evaluating the reading level acquired by students and the possibility of certifying it according to the Common European Framework of Reference.

\subsection{Structure of the MRP method and its application to readings}

What is a portfolio?

It is a file or folder that contains a collection of student work. The portfolio must include, at least, one task of each type of written text about the readings worked both in the academic context and outside it.

\section{So, what is MRP?}

MRP will be a very useful tool for students to develop their reading skills at each assigned level within the Common European Framework of Reference for Languages.

MRP is designed to collect all the readings and linguistic knowledge acquired both in class and outside of it. It is conceived as a personal, non-transferable and dynamic document for the students. They must sign in regularly in order to evaluate their progress and influence the aspects that need further study.

My portfolio consists of three well differentiated parts: passport, biography and dossier.

1. My Reader Passport reports on the holder's reading skills based on a summary of his reading experiences.

2. My Reader Biography aims to help the student to reflect on his linguistic history, his abilities and his progress and learning plans.

3. Dossier of materials including, on the one hand, a selection of work samples carried out in correlation with the curriculum and, on the other hand, a selection of written or recorded materials.

\section{Objectives}

The main objective of this research is the development of a new tool (PLIA) and a digital methodology (MRP) in the classroom in order to improve the reading skills of primary and secondary school students. At the same time, from the teacher's point of view, we cover the need to go beyond traditional methodology to promote the enjoyment of reading, leaving behind the master classes in which students listen to the teacher and remain passive.

The new tool and methodology are based on three fundamental pillars: digital competences, the digitization of reading work and the assessment of reading skills. From here, the list of specific objectives that we can achieve is shown in Tab. 1.

Table 1: Specific objectives that we can achieve with the PLIA platform.

\begin{tabular}{|l|l|l|}
\hline Digital skills & Digitization of reading work & Reading skills assessment \\
\hline $\begin{array}{l}\text { Increase digital } \\
\text { competence. }\end{array}$ & Digitize the reading plans. & $\begin{array}{l}\text { Systematize the reading work to reduce } \\
\text { the effort of the teaching staff. }\end{array}$ \\
\hline & $\begin{array}{l}\text { Achieve greater efficiency in the } \\
\text { time devoted to reading by students. }\end{array}$ & $\begin{array}{l}\text { Establish a shared assessment strategy in } \\
\text { the classroom. }\end{array}$ \\
\hline
\end{tabular}




\section{2nd World Conference on Teaching and Education}

\begin{tabular}{|l|l|l|}
\hline & $\begin{array}{l}\text { Increase the quality of the linguistic } \\
\text { competence of students. }\end{array}$ & $\begin{array}{l}\text { Create an instrument for collecting } \\
\text { parameters to support users. }\end{array}$ \\
\hline & $\begin{array}{l}\text { Offer the analysis of the evolution in their } \\
\text { metacognitive development as readers. }\end{array}$ \\
\hline
\end{tabular}

The main reason for the rejection of reading is the tedium that arouses in students since it requires a long time and an intellectual effort. This means that reading cannot compete with the immediacy of the new technologies to which they are accustomed just clicking a button (Ruiz et al., 2012).

The motivation that new technologies awaken in young people must be used to carry out efficient reading work in which the impulse of digitization leads them to develop a taste for reading in an enjoyable and fun way. Thus, giving them simple guidelines in each reading session and testing their reading competence, they can access countless opportunities and experiences. PLIA makes it possible to dynamize the reading task by dividing the work into specific and smaller tasks. In this way, students will have a sense of superior progress which will not only increase efficiency in terms of time spent reading but will also increase student motivation and interest in tackling the following tasks or milestones, fostering a spirit of improvement.

Due to the large number of students in each group, it is very difficult for them to work more than one reading per school term in classroom with the current traditional methodology. But if we manage to move to a digital platform, we can increase the number of readings made, as well as improve in all comprehension, action and reading speed indices.

One of the requirements for students to increase school performance is that teachers overcome the cumbersome aspect of their correction work by working with data in a systematic way, thus favouring the promptness of the results and the recommendation and personalization of the intervention according to the characteristics and interactions of each individual, as well as the level of reading comprehension that they demonstrate. Thanks to PLIA, this saturation in correction tasks will be avoided, allowing teachers not only to grade, but also to focus part of their efforts on helping to achieve reading objectives and improving the skills of their students.

On the other hand, with the traditional methodology, teachers are not allowed to trace a participatory path so that the student's learning is more active and meaningful. Through PLIA, teachers can implement mixed teaching strategies in which traditional and digital techniques converge for the evaluation of students' reading skills. With this co-assessment, it is possible to program and automate the assessment of language skills in class and ensure a follow-up of them by the teacher. In addition, due to the systematization of tasks, the student has real-time information on his progress.

Obtaining the level of linguistic competence of the students is a very arduous and complicated work and even more so with large groups in the classrooms. Using a digital platform designed for the assessment of the reading level, users could carry out a series of tests related to comprehension, speed and reading action that will allow them to immediately identify which is their level, and which ones are their shortcomings. Furthermore, thanks to the automation in the collection of parameters and information, it is possible to increase the number of reading tests carried out in the classroom. 


\section{2nd World Conference on Teaching and Education}

It is a great added value in the daily activity of a teacher to have certain reading parameters in the classroom (Ramírez-Montoya \& Lugo-Ocando, 2020). The parameters allow us to identify the evolution of the metacognitive development of students as readers, thus allowing to identify if the reading level of the students corresponds to their curricular level and, furthermore, to identify those students who have difficulties. In this way, PLIA allows, on the one hand, to analyse the global level of each class, allowing teachers to design itineraries and modular teaching plans adapted to the needs of the students; and, on the other hand, to increase the capacity and speed of action of the teacher in the detection of deviations in the training itineraries designed.

\section{Methodology}

One of the drawbacks of the traditional methodology is that the reading plans that are designed in each educational center suffer from the difficulty of increasing the efficiency in the time dedicated to reading, since it is not possible to carry out many readings during a school year. To overcome this obstacle, it is necessary to digitize it using platforms or software tools. In our case, a platform called "interactive platform for the promotion of reading (PLIA)" has been developed. It has been implemented with web technologies which makes it much easier to use from any device with a browser and basic internet access. The application is subdivided into three modules that correspond to the three fundamentals in Tab. 1.

Digital skills are developed using the platform modules "My Reader Passport" and "My Reader Biography" that allow generating the student's reading history. Data are filled in dynamically through a series of windows and forms with "My Reader Passport". First, the reader card is completed with personal data and then, the library data (Fig. 1).

"My Reader Dossier" allows the user to work dynamically on the readings they do in class, at home or in the library. Once this section is reached, the student has two options: "My Readings" and "My Individual Reading Plan". Within "My Readings", the student can consult all the readings that he has worked in with the platform. Thus, at a glance, teachers can consult the main data of the books that have been worked on and download a report in PDF format.

Within "My Individual Reading Plan", users can start new reading assignments that they carry out in the library, at school or at home. At first, the platform requests the language in which the reading will be worked (Spanish or English) and the reading plan (regular plan or attention to diversity) before starting a new reading.

Each reading session is made up of three sections. In the first section, the user will complete a personal dictionary with the words that are unknown in each reading session. Furthermore, by clicking on the red button next to each word, the user will be redirected to the official website of the Royal Spanish Academy, where the meaning of the unknown word will be shown.

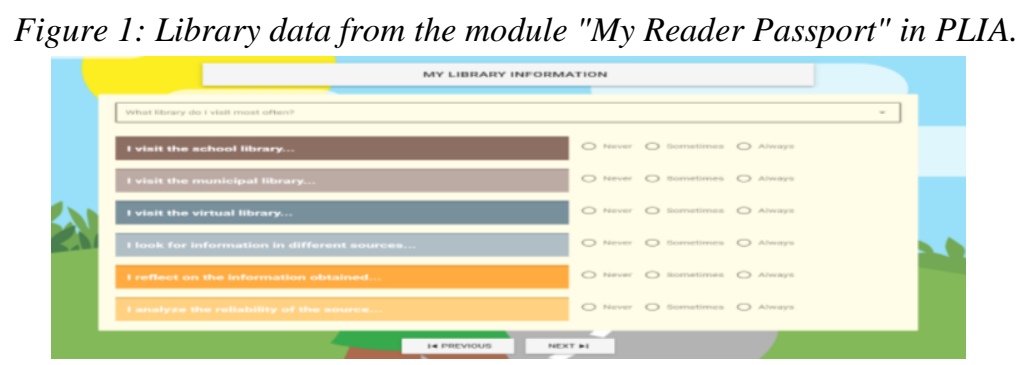

215 


\section{2nd World Conference on Teaching and Education}

\section{9-21 February, $2021 \quad$ Vienna, AUSTRIA}

In the second section of each reading session, the user will have to answer a series of questions regarding the content of the book that will vary depending on the level of reading progress.

At this point in the session, the user will be assisted by "My Words Chest" shown in Fig. 2. Here, a repository with a series of words that may be useful for the student to complete the questions proposed in each session will be displayed.

In addition, each session will develop a glossary that includes unknown words, primitive words and derived words.

Regarding the role of teachers, their work is much less arduous when it comes to monitoring the reading work and correcting the assigned tasks. Likewise, it will be more complete, since it makes it possible to address the monitoring of all the skills related to reading.

The assessment of reading skills is developed using the platform module called "My Reading Level". The parameters used to analyze the evolution of the metacognitive development of users in their reading work include the three skills that complete linguistic competence: reading, written expression and oral expression. Regarding to reading, certain minimums are established in terms of comprehension, speed and reading action so the students' level can be easily identified. It corresponds to the curricular level they are studying. As for writing, the parameters focus on the correctness of the expression and its adequate presentation. And, finally, to address the assessment of oral skills in this module, the selected content, its organization for staging and the expression used are evaluated.

Figure 2: My Words Chest in PLIA.

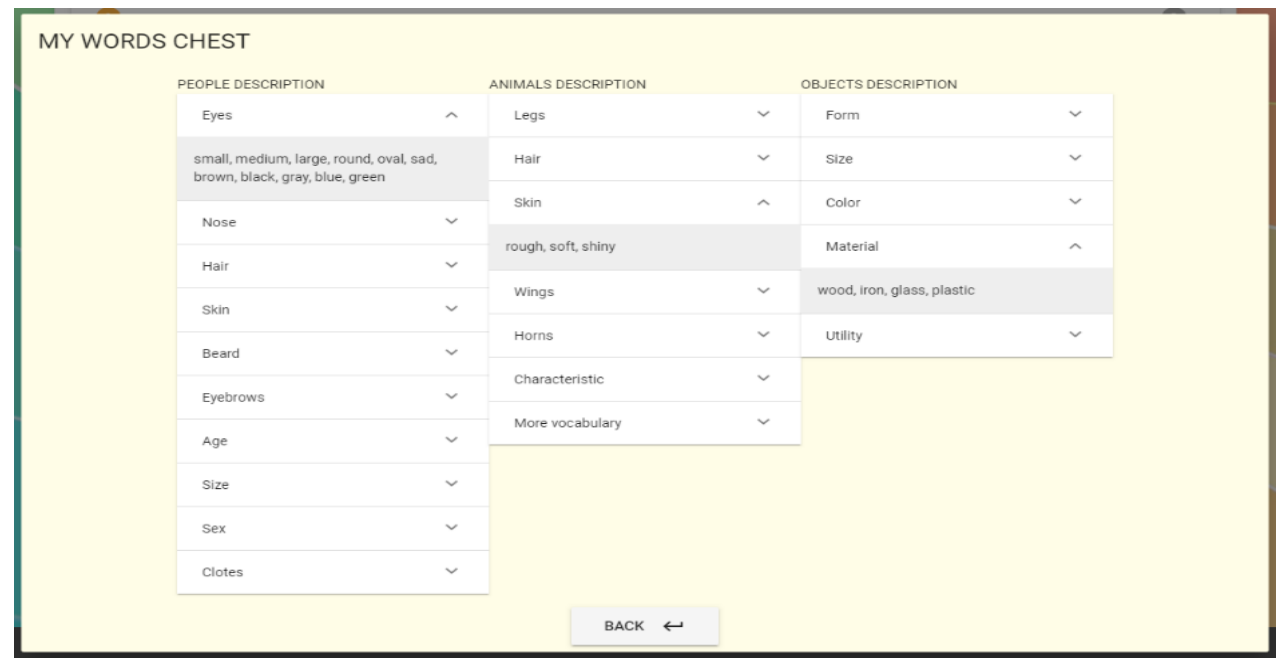

From the "My Reading Level" tab, users will find three sections. In each one of them, they can work on reading comprehension, reading speed and reading action, respectively. In each section, a test will be carried out to measure the student's reading level in each field.

The reading comprehension test assesses the ability to understand a text. The student begins the test by reading a text offered by the platform. And after the completion of the reading, the student has to answer a series of multiple-choice questions about it. Once the test has been completed, the reader is shown a window with his score obtained from zero to ten points. 


\section{2nd World Conference on Teaching and Education}

\section{9-21 February, $2021 \quad$ Vienna, AUSTRIA}

In the reading speed test, the user must read a text provided by the platform. Depending on the time spent reading, the number of words read per minute and the corresponding reading level are calculated. At the end of the test, the grade is obviously displayed. In this specific test, it is necessary to have the PC sound activated. In the first place, the student will have to listen to a text paying special attention to the length of the pauses and the intonation of the narrator.

In the case of the reading action test, the student is asked to complete a text with the corresponding punctuation, exclamation or question marks after listening to it,. The narrator will start reading the text a second time automatically, and the audio will stop at each blank space for the student to fill in with the appropriate sign.

Again, the score obtained from 0 to 10 points will be displayed on the screen after the test. The results of all the tests that the student takes can be consulted from the main page of the application in the "My Results" section thus checking the progress.

Figure 3: Grades list in PLIA reading speed tests.

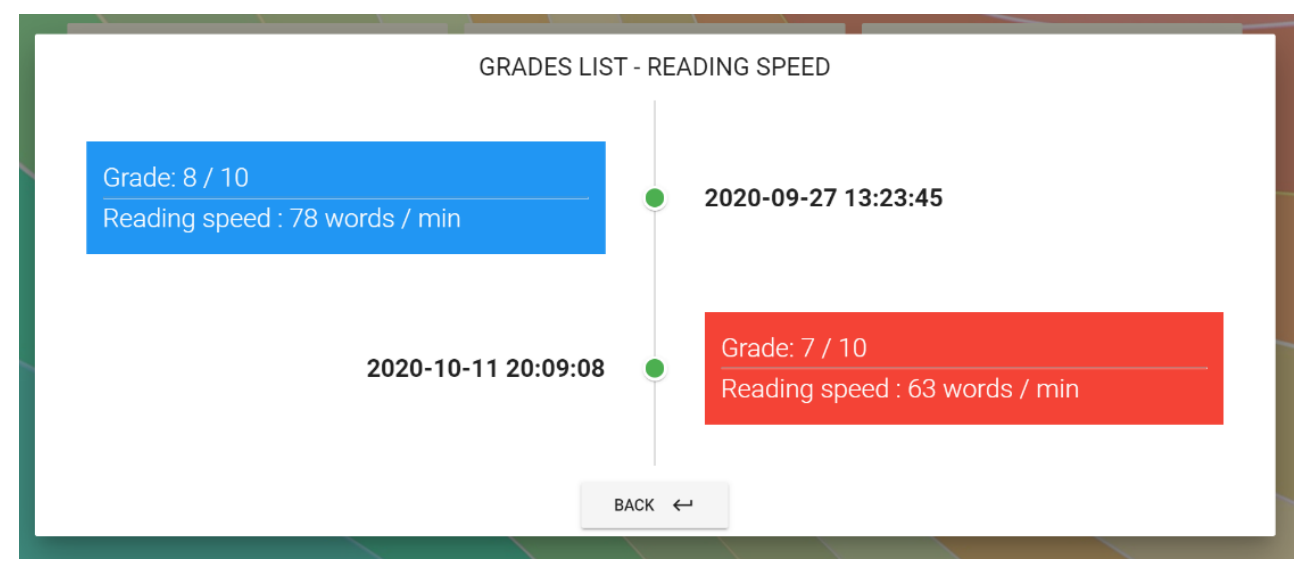

Fig. 3 shows an example of the tests carried out by a user in chronological order, showing the grade obtained and other relevant information such as the number of words read per minute.

\subsection{Context of the intervention and participants}

After the development of the platform and according to the previously defined methodology, a pilot test was carried out to put it into practice.

The intervention took place in three educational centers located in the Region of Murcia, Spain: primary schools "San Juan Bosco-Salesianos" located in Cartagena and "San Pablo" located in Abarán, and the secondary education center "IES Diego Tortosa" located in the municipality of Cieza.

The test was carried out between the months of December and March, coinciding with the second term of the 2019-2020 school year. The sample was made up of 220 participants, including 60 teachers and 160 students. 42 of them, were primary school students from the first and second cycle; 74 were third cycle primary school students and 44 first and second year secondary school students.

During the experience, the teachers used PLIA as a support tool in the evaluation and monitoring of the students' reading work both in the classroom and at home. The students used 


\section{2nd World Conference on Teaching and Education}

PLIA as a platform to work on their reading skills and abilities. At first, the students used the platform to work on the readings done in class and at home. In parallel, PLIA was used as an instrument in the classroom to carry out reading tests and to collect parameters and information.

\section{Results \& Discussion}

During the pilot period, all the reading activity of the participating students was registered by the PLIA platform. Data were collected regarding the number of readings worked, number of tests performed (comprehension, speed and action) as well as the grades obtained. Tab. 2 shows a summary of the data reported by PLIA.

Table 2: Reading parameters reported by PLIA for a group of 160 students over 3 months in the 2019-2020 academic year.

\begin{tabular}{|l|c|c|c|c|c|}
\hline \multirow{2}{*}{ Academic year } & Readings & \multicolumn{4}{|c|}{ Reading tests } \\
\cline { 2 - 6 } & $\begin{array}{c}\text { \# readings } \\
\text { per student }\end{array}$ & $\begin{array}{c}\text { \# comprehension } \\
\text { tests per student }\end{array}$ & $\begin{array}{c}\text { \# speed tests } \\
\text { per student }\end{array}$ & $\begin{array}{c}\text { \# action tests } \\
\text { per student }\end{array}$ & $\begin{array}{c}\text { Total \# tests } \\
\text { per student }\end{array}$ \\
\hline Primary [1-4] & 1,26 & 1,90 & 0,52 & 0,69 & 3,11 \\
\hline Primary [5-6] & 1,05 & 1,37 & 0,28 & 0,44 & 2,09 \\
\hline Secondary [1-2] & 1,09 & 1,66 & 0,18 & 0,23 & 2,07 \\
\hline
\end{tabular}

Simultaneously, a subset of 15 of the teachers participating in the pilot made an estimate of the same reading parameters under study, but this time, obtained in the classroom over the same period of the previous year 2018-2019 without the use of any digital support tool in the classroom. The results are shown in Tab. 3.

Table 3: Reading parameters reported by 15 teachers obtained throughout the second quarter of the 2018-2019 academic year in educational centers in the Region of Murcia, Spain

\begin{tabular}{|l|c|c|c|c|c|}
\hline \multirow{2}{*}{ Academic year } & Readings & \multicolumn{4}{|c|}{ Reading tests } \\
\cline { 2 - 6 } & $\begin{array}{c}\text { \# readings } \\
\text { per student }\end{array}$ & $\begin{array}{c}\text { \# comprehension } \\
\text { tests per student }\end{array}$ & $\begin{array}{c}\text { \# speed tests } \\
\text { per student }\end{array}$ & $\begin{array}{c}\text { \# action tests } \\
\text { per student }\end{array}$ & $\begin{array}{c}\text { Total \# tests } \\
\text { per student }\end{array}$ \\
\hline Primary [1-4] & 1,00 & 1,15 & 0,16 & 0,06 & 1,37 \\
\hline Primary [5-6] & 0,98 & 1,20 & 0,12 & 0,10 & 1,42 \\
\hline Secondary [1-2] & 1,05 & 1,30 & 0,05 & 0,12 & 1,47 \\
\hline
\end{tabular}

Fig. 4 shows a comparison between the reading parameters of the students throughout a school term. The graphs show the data reported by the PLIA platform and the data obtained in the same period without the use of any type of digital support platforms in the classroom.

Enhancing the promotion of reading through the use of new digital tools and methodologies in the classroom is not an easy task. The inclusion of new technologies in fields as consolidated as in education presents an added difficulty since its evaluation of use not only depends on the results obtained but on the acceptance and experience of the end users who, at the end, are students and teachers.

In this study, the results have been obtained from two sources: interviews with users about their opinions about PLIA and the reading data collected by the platform.

In a first qualitative evaluation of the results, we can affirm that the PLIA tool has contributed satisfactorily to the promotion of reading in the classroom. In the first place, the teachers affirm that the experience with the application and the results obtained have been good or very good. In the interviews with the teaching staff, one of the most outstanding aspects has been the reduction in the time spent on repetitive tasks such as corrections and collecting 


\section{2nd World Conference on Teaching and Education}

\section{9-21 February, 2021 \\ Vienna, AUSTRIA}

reading parameters thanks to the tool. On the other hand, the platform has had a notable acceptance among students. A greater predisposition and motivation for reading work in digital environments has been detected, as well as an increase in student participation in the classroom. In the surveys carried out after three months of using the application, it was observed that part of the students experienced a more playful perception of reading activity.

Figure 4: Comparison of reading results in the classroom. Use of traditional teaching methodologies vs Use
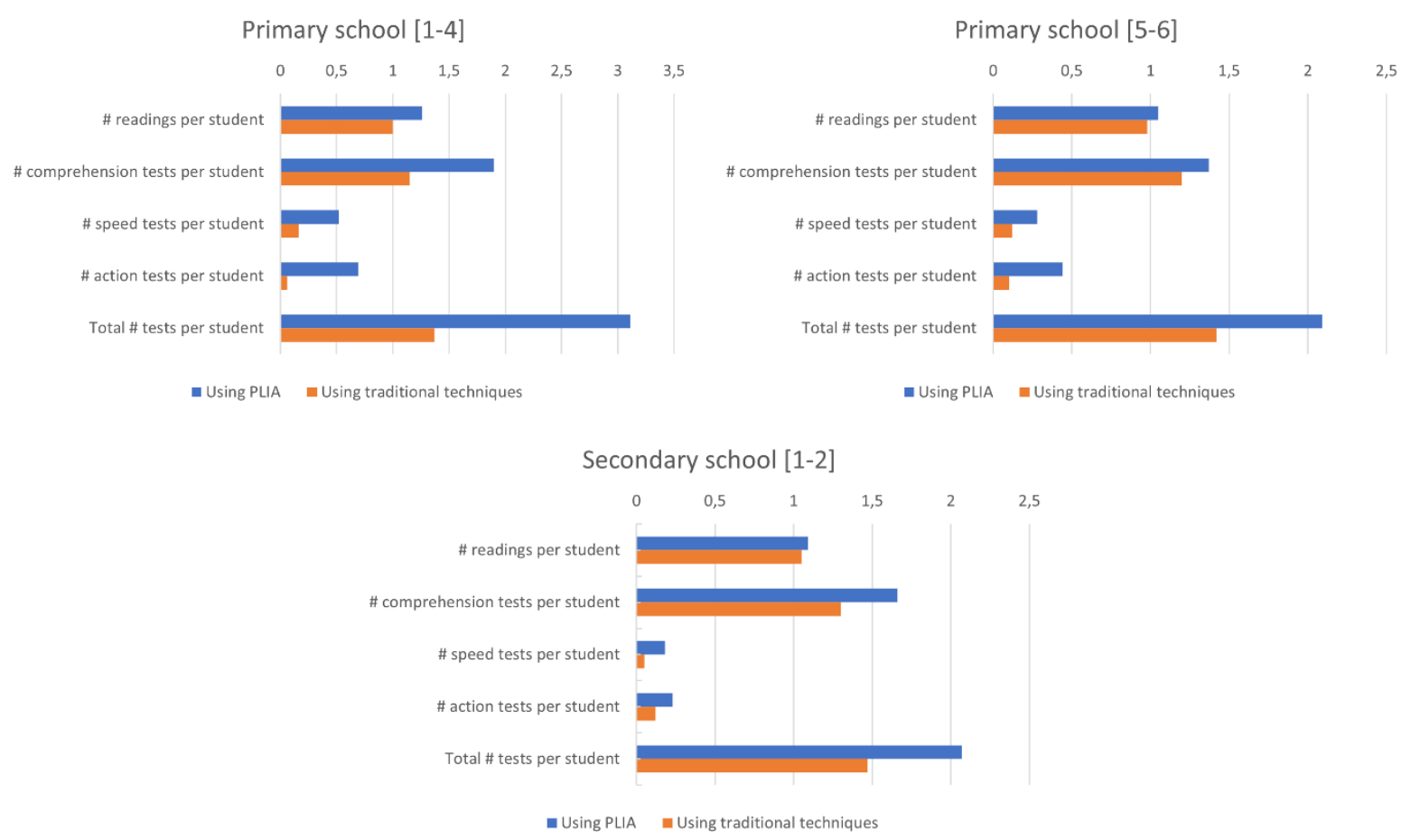

of the PLIA digital tool over 3 months in educational centers in the Region of Murcia, Spain.

Regarding the quantitative results, the reading data reported by the platform is shown in line with the experience of use of teachers and students. A first conclusion can be drawn from previous Fig. 4: in general terms, the use of PLIA in the classroom has made it possible to carry out a greater number of readings and reading tests.

A more detailed analysis focusing on the number of readings carried out reveals how primary school students between the first and fourth grades have worked $26 \%$ more readings with the use of PLIA. However, students in the last cycle of primary and secondary school have barely increased the number of readings carried out by $10 \%$. This reduction of improvement has been due to the greater workload that the students support in higher courses despite a greater predisposition has been detected towards tackling their reading tasks.

As for the reading tests, there has been a notable increase in their performance. The greatest increase has occurred among students from first to fourth grade of primary school who have taken $127 \%$ more reading tests during the pilot of the application. These are followed by lastcycle primary school students with an increase of $47.18 \%$ and, lastly, secondary school students with an increase of $40.82 \%$. 


\section{2nd World Conference on Teaching and Education}

\section{9-21 February, $2021 \quad$ Vienna, AUSTRIA}

Analyzing the topic of the reading tests (comprehension, speed and action), an equitable increase in the number of tests performed between each of the categories can be observed in Fig. 4. However, the speed and action tests stand out. As can be seen in the graph, the teachers were rarely able to take speed or reading action tests in the classroom due to the lack of time and the technical difficulty associated with carrying out these types of tests in such large classes. Due to this phenomenon, most of the evaluations carried out focused on the performance of reading comprehension tests. With the use of PLIA, the automation of tests and the collection of metrics such as reading time and words read per minute, it has been even possible in some scenarios to introduce speed and reading action tests in the classroom.

\section{Conclusions}

The PLIA platform presented in this work encourages reading by digitizing the reading task. It involves the family in the learning process of their children. It offers a point of joint reflection between students, teachers and families to establish objectives and learning strategies, selfevaluation and co-evaluation. It can help the faculty to make joint decisions to elaborate the linguistic project of the centers and it contributes to the existence of a unique and nontransferable document for each student with his/her "Reading History", thus:

1. Promoting the early diagnosis of difficulties from the Guidance Department in the pertinent cases.

2. Letting institutions to verify good academic results by identifying the quantitative result of the reading level of a specific student, group, course, center or entire province.

\section{References}

Comunidad Autónoma de la Región de Murcia. (2014). Decreto n. ${ }^{\circ}$ 198/2014, de 5 de septiembre (BORM, 6/09/14), por el que se establece el currículo de la Educación Primaria en la CARM. Available: https://www.borm.es/borm/documento?obj=anu\&id=713895

Comunidad Autónoma de la Región de Murcia. (2014). Orden de 20 de noviembre de 2014 (BORM, 22/11/14), de la Consejería de Educación, Cultura y Universidades por la que se regula la organización y la evaluación en la Educación Primaria en la CARM. Available: https://www.borm.es/borm/documento?obj=anu\&id=718839

Comunidad Autónoma de la Región de Murcia. (2015). Decreto n. ${ }^{\circ} 220 / 2015$, de 2 de septiembre de 2015 (BORM, 3/09/15), por el que se establece el currículo de Educación Secundaria Obligatoria en la CARM. Available: https://www.borm.es/borm/documento?obj=anu\&id=735576

Comunidad Autónoma de la Región de Murcia. (2015). Decreto n. ${ }^{\circ}$ 221/2015, de 2 de septiembre de 2015 (BORM, 3/09/15), por el que se establece el currículo del Bachillerato en la CARM. https://www.borm.es/borm/documento?obj=anu\&id=735577

Council of Europe. (2002). Common European Framework for Languages: Learning, Teaching, Assessment. Language Policy Unit, Strasbourg. Available: https://rm.coe.int/16802fc1bf

Guisado, A. C. (2008). "El portfolio como estrategia de evaluación compartida de la comprensión lectora". Didáctica: Lengua y Literatura, vol. 20, pp. 15-36. 


\section{2nd World Conference on Teaching and Education}

\section{9-21 February, 2021}

Vienna, AUSTRIA

Moreno-Fernández, O., Moreno-Crespo, P. (2017). "El portafolio digital como herramienta didáctica: una evaluación crítica de fortalezas y debilidades". Revista de Humanidades, vol. 30, pp. 11-30. Available: http://e-spacio.uned.es/fez/view/bibliuned:revistaRH-2017-30-5000

Puig, F. (2008). "El Marco Común Europeo de Referencia y la evaluación en el aula". Monográficos marco ELE, vol. 7, pp. 78-91. Available: http://marcoele.com/el-marco-comun-europeo-dereferencia-y-la-evaluacion-en-el-aula/

Ramírez-Montoya, M., Lugo-Ocando, J. (2020). "Systematic review of mixed methods in the framework of educational innovation". Revisión sistemática de métodos mixtos en el marco de la innovación educativa, revista Comunicar, vol. 65, pp. 9-20.

Ruiz, J. A., Giménez, D. G., Migueláñez, N. G., Serra, R. M. M., Vega, N. P., Burillo, M. I. R. y Rubio, N. V. (2012). Tonto el que no lea. Enseñar lengua y literatura castellanas en la era digital. 1st ed., Lérida, Spain: Edicions de la Universitat de Lleida.

Vázquez, M. A. (2010). Las aulas de lectura: una propuesta global para el fomento de la lectura en/desde la Universidad, Álabe: Revista de la Red de Universidades Lectoras, vol. 2, pp. 1-15. 